\title{
SINTESIS DAN KAJIAN PERILAKU KONDUKTIVITAS KOMPOSISI BARU ELEKTROLIT PADAT $\left(\mathrm{Li}_{2} \mathrm{O}\right)_{\mathbf{x}}\left(\mathbf{P}_{2} \mathrm{O}_{5}\right)_{\mathbf{y}}$
}

\author{
Heri Jodii ${ }^{1,2}$, Anne Zulfia S. ${ }^{1}$, Agus Sudjatno ${ }^{2}$, Wahyudianingsih ${ }^{2}$ dan E. Kartini ${ }^{2}$ \\ ${ }^{\prime}$ Departemen Teknik Metalurgi dan Material, Fakultas Teknik - UI \\ Kampus UI Depok, Jawa Barat 16424 \\ ${ }^{2}$ Pusat Sains dan Teknologi Bahan Maju (PSTBM) - BATAN \\ Kawasan Puspiptek, Serpong15314, Tangerang Selatan \\ E-mail: herieldi@batan.go.id
}

Diterima: 2 Februari 2017 Diperbaiki: 6 Oktober $2017 \quad$ Disetujui: 13 Oktober 2017

\begin{abstract}
ABSTRAK
SINTESIS DAN KAJIAN PERILAKU KONDUKTIVITAS KOMPOSISI BARU ELEKTROLIT PADAT $\left(\mathbf{L i}_{2} \mathbf{O}\right)_{\mathbf{x}}\left(\mathbf{P}_{2} \mathbf{O}_{5}\right)_{\mathbf{y}}$. Bahan elektrolit padat $\left(\mathrm{Li}_{2} \mathrm{O}\right)_{\mathrm{x}}\left(\mathrm{P}_{2} \mathrm{O}_{5}\right)_{\mathrm{y}}$ dengan komposisi konten $\mathrm{Li}_{2} \mathrm{O}$ sebesar $\mathrm{x}=24 \%$ berat dan $28 \%$ berat telah dipreparasi menggunakan teknik reaksi padat pada suhu di bawah suhu lelehnya. Paduan yang telah dipreparasi kemudian dikarakterisasi menggunakan Scanning Electron Microscopy (SEM) dan Electrochemical Impedance Spectroscopy (EIS) untuk diperiksa morfologi, sifat elektrokimia dan konduktivitasnya. Karakterisasi elektrokimia menunjukkan bahwa nilai konduktivitas kedua paduan berada pada orde $10^{-6} \mathrm{~S} / \mathrm{cm}$, setara dengan nilai konduktivitas paduan $\mathrm{Li}_{4} \mathrm{P}_{2} \mathrm{O}_{7}$ yang dipreparasi pada suhu lebih tinggi dengan kandungan $\mathrm{Li}_{2} \mathrm{O}$ lebih banyak, dan lebih tinggi dari konduktivitas senyawa $\mathrm{Li}_{3} \mathrm{PO}_{4}$. Taksiran nilai eksponen frekuensi dari formula konduktivitas AC, memperlihatkan bahwa kemungkinan sumber konduksi ion dalam bahan yang diamati salah satunya adalah aliran ion jarak jauh. Kurva rugi dielektrik menunjukkan bahwa konduksi dalam bahan elektrolit ini didominasi oleh konduksi DC.
\end{abstract}

Kata kunci: Elektrolit padat, Lithium Fosfat, Electrochemical Impedance Spectroscopy, Konduktivitas, Dielektrik

\begin{abstract}
A SYNTHESIS AND CONDUCTIVITY STUDY OF NEW COMPOSITION OF $\left(\mathrm{Li}_{2} \mathrm{O}\right)_{\mathbf{x}}\left(\mathrm{P}_{2} \mathrm{O}_{5}\right)_{\mathbf{y}}$ SOLID ELECTROLYTE. $\left(\mathrm{Li}_{2} \mathrm{O}\right)_{\mathrm{x}}\left(\mathrm{P}_{2} \mathrm{O}_{5}\right)$ solid electrolyte with $\mathrm{Li}_{2} \mathrm{O}$ content $\mathrm{x}=24$ and $28 \mathrm{wt} \%$ were prepared by solid reaction technique under the melting temperature. The prepared compounds were characterized using Scanning Electron Microscopy (SEM) and Electrochemical Impedance Spectroscopy measurements (EIS) in order to investigate their morphology, electrochemical properties, and conductivity behavior. The electrochemical characterization indicated that the conductivity value of the both compounds was in order of $10^{-6} \mathrm{~S} / \mathrm{cm}$, in the same order with that of $\mathrm{Li}_{4} \mathrm{P}_{2} \mathrm{O}_{7}$ that prepared at higher temperature with more $\mathrm{Li}_{2} \mathrm{O}$ content, and three order higher than that of $\mathrm{Li}_{3} \mathrm{PO}_{4}$ compounds. The value of evaluated power law exponent of AC conductivity reveals that the long-range drift of ions may be one of the sources of ion conduction in the observed samples. The slope of dielectric loss indicates that the conduction in the samples were more predominantly DC conduction.
\end{abstract}

Keywords: Solid electrolytes, Lithium Phosphate, Electrochemical Impedance Spectroscopy, Conductivity, Dielectric

\section{PENDAHULUAN}

Penggunaan elektrolit tipe cair pada divais elektronik seperti baterai, menjadi salah satu penyebab hilangnya kapasitas baterai yang tidak bisa dipulihkan yang berakibat pada penurunan waktu hidup baterai. Hal tersebut dikarenakan terjadinya lapisan stabil di daerah antar muka elektroda dan elektrolit, yang dihasilkan dari reaksi redoks di dalam baterai selama proses pembebanan dan pelepasan muatan (charge discharge) [1]. Penggunaan elektrolit tipe cair juga mengakibatkan pada terbatasnya rentang suhu 
pemakaian baterai, usia siklus pakai yang lebih pendek dan menjadi salah satu penyebab kebocoran elektrolit pada baterai [2]. Penggantian elektrolit tipe cair dengan elektrolit padat, menjadi persoalan yang menarik untuk mengatasi permasalahan tersebut.

Elektrolit padat memiliki potensi yang besar untuk diaplikasikan dalam berbagai bentuk divais elektronik, dengan beberapa kelebihan seperti tidak mengakibatkan kebocoran, lebih tahan terhadap panas dan memiliki ketahanan terhadap benturan dan getaran yang lebih baik dibandingkan dengan elektrolit cair [3]. Selain itu, elektrolit padat juga merupakan konduktor ion tunggal, yang berarti hanya mengalirkan satu jenis ion pembawa muatan sehingga sangat menguntungkan untuk mengurangi kemungkinan baterai overpotensial [4]

Lithium phosphate $\left(\mathrm{Li}_{3} \mathrm{PO}_{4}\right)$ merupakan satu senyawa elektrolit padat stabil dari paduan $\mathrm{Li}_{2} \mathrm{O}-\mathrm{P}_{2} \mathrm{O}_{5}$ yang banyak dipelajari karena memiliki titik leleh yang cukup rendah, komposisi yang sederhana, tidak beracun dan karakter pembentuk gelas yang kuat. Preparasinya bisa dilakukan dengan teknik pendinginan cepat (melt quenching) atau juga dengan reaksi kimia biasa[5]. Namun senyawa ini memiliki resistansi bulk yang besar sehingga konduktivitasnya menjadi rendah sekitar $10^{-9}-10^{-8} \mathrm{~S} / \mathrm{cm}$. Beberapa penelitian dilaporkan telah melakukan analisis tentang struktur senyawa ini, melalui karakterisasi sinar-X [6], karakterisasi neutron [7] dan melalui simulasi komputer [8,9]. Penelitian tentang morfologi senyawa ini juga telah dilaporkan dengan investigasi menggunakan Scanning Electron Microscopy (SEM) [10].

Untuk meningkatkan nilai konduktivitas sebuah sistem elektrolit padat, cara yang paling efektif adalah dengan mencampurkan dua atau lebih spesi pembentuk anion yang berbeda sehingga akan terjadi mixed former effect di dalam sistem tersebut [11]. Beberapa penelitian dilaporkan telah melakukan modifikasi sistem $\mathrm{Li}_{2} \mathrm{O}-\mathrm{P}_{2} \mathrm{O}_{5}$ dengan menambahkan oksida-oksida seperti $\mathrm{Al}_{2} \mathrm{O}_{3}, \mathrm{TiO}_{2}$ $\mathrm{GeO}_{2}$ dan $\mathrm{SiO}_{2}$ [12-14]. Konduktivitas tertinggi dilaporkan mencapai angka $10^{-3} \mathrm{~S} / \mathrm{cm}$ untuk sistem $\mathrm{Li}_{2} \mathrm{O}-\mathrm{Al}_{2} \mathrm{O}_{3}-\mathrm{TiO}_{2}$ $\mathrm{P}_{2} \mathrm{O}_{5}$ pada suhu kamar [12]. Beberapa penelitian dilaporkan juga melakukan modifikasi dengan memberikan dopping AgI, LiI atau $\mathrm{Na}_{2} \mathrm{O}$ [15-17]. Modifikasi paduan $\mathrm{Li}_{2} \mathrm{O}-\mathrm{P}_{2} \mathrm{O}_{5}$ dengan menambahkan clay montmorillonite (MMT) dalam bentuk komposit juga dilaporkan mampu menaikkan konduktivitas paduan [18]. Pembuatan lapisan tipis paduan $\mathrm{Li}_{2} \mathrm{O}-\mathrm{P}_{2} \mathrm{O}_{5}$ dalam lingkungan Nitrogen juga dilaporkan mampu menurunkan resistansi bulk paduan dan meningkatkan konduktivitasnya[19].

Kajian tentang konduktivitas paduan $\mathrm{Li}_{2} \mathrm{O}_{-} \mathrm{P}_{2} \mathrm{O}_{5}$ telah dilaporkan dalam berbagai komposisi stoikiometri x $\mathrm{Li}_{2} \mathrm{O}$.y $\mathrm{P}_{2} \mathrm{O}_{5}$, dengan kandungan $\mathrm{Li}_{2} \mathrm{O}$ sebanyak 17,4 \%berat, 29,6 \%berat, 38,7 \%berat, 45,7 \% berat dan 51,3\%berat [7,20]. Paduan disintesis dengan teknik reaksi padatan dengan pendinginan cepat dari suhu di atas titik lelehnya. Pada komposisi $\mathrm{Li}_{2} \mathrm{O}$ sebesar 17,4 \% berat paduan $\mathrm{Li}_{2} \mathrm{O}-\mathrm{P}_{2} \mathrm{O}_{5}$ dilaporkan memiliki struktur amorf, sedangkan pada komposisi lainnya memiliki struktur kristalin, dimana konduktivitas tertinggi dilaporkan dimiliki oleh paduan dengan komposisi $\mathrm{Li}_{2} \mathrm{O}$ sebanyak 29,63 \%berat, yang memberikan struktur kristalin $\mathrm{Li}_{4} \mathrm{P}_{2} \mathrm{O}_{7}$ dengan konduktivitas sebesar $\sigma=6,78 \times 10^{-6} \mathrm{~S} / \mathrm{cm}[20]$.

Di sisi lain, Nakano, dkk mengusulkan diagram fasa yang menunjukkan bahwa paduan $\mathrm{Li}_{2} \mathrm{O}-\mathrm{P}_{2} \mathrm{O}_{5}$ akan membentuk senyawa $\mathrm{Li}_{4} \mathrm{P}_{2} \mathrm{O}_{7}$ pada suhu diatas $600^{\circ} \mathrm{C}$, di rentang komposisi kandungan $\mathrm{Li}_{2} \mathrm{O} 21,24 \leq \mathrm{x} \leq 29,63$ \%berat [21]. Pada daerah ini, titik leleh paduan akan meningkat seiring dengan penambahan kandungan $\mathrm{Li}_{2} \mathrm{O}$, dan mencapai titik leleh maksimum pada komposisi kandungan $\mathrm{Li}_{2} \mathrm{O}$ sebesar 29,63\% komposisi stoikiometri $\mathrm{Li}_{4} \mathrm{P}_{2} \mathrm{O}_{7}$, yaitu $885{ }^{\circ} \mathrm{C}$. Pada komposisi $\mathrm{x} \leq 21,24 \%$ berat, $\mathrm{Li}_{4} \mathrm{P}_{2} \mathrm{O}_{7}$ membentuk eutektik dengan $\mathrm{LiPO}_{3}$ pada suhu $600{ }^{\circ} \mathrm{C}$, dan pada daerah $\mathrm{x} \geq 29,63$ \% berat, $\mathrm{Li}_{4} \mathrm{P}_{2} \mathrm{O}_{7}$ membentuk eutektik dengan $\mathrm{Li}_{3} \mathrm{PO}_{4}$ pada suhu $870^{\circ} \mathrm{C}$. Dari kedua hasil tersebut bisa disimpulkan bahwa terdapat kemungkinan untuk mendapatkan paduan dengan konduktivitas tinggi dengan titik leleh lebih rendah dan kandungan $\mathrm{Li}_{2} \mathrm{O}$ lebih sedikit pada rentang 21,24 $\leq \mathrm{x} \leq 29,63 \%$ berat.

Pada penelitian ini telah dibuat paduan $\left(\mathrm{Li}_{2} \mathrm{O}\right)_{\mathrm{x}}\left(\mathrm{P}_{2} \mathrm{O}_{5}\right)_{\mathrm{y}}$ dengan komposisi $\mathrm{Li}_{2} \mathrm{O}$ sebesar $\mathrm{x}=24 \%$ berat dan $28 \%$ berat menggunakan teknik pelelehan pada suhu lebih rendah dari titik leleh $\mathrm{Li}_{4} \mathrm{P}_{2} \mathrm{O}_{7}$, dilanjutkan dengan pendinginan cepat (quenching). Morfologi sampel hasil preparasi selanjutnya diinvestigasi menggunakan $S E M$, sedangkan sifat elektrokimia sampel dikarakterisasi menggunakan alat EIS, meliputi karakter impedansi, konduktivitas dan sifat dielektrik paduan. Kedua paduan menunjukkan morfologi yang hampir sama. Sedangkan hasil pengukuran sifat elektrokimia menunjukkan bahwa paduan-paduan ini memiliki nilai konduktivitas yang lebih tinggi dari nilai konduktivitas senyawa $\mathrm{Li}_{3} \mathrm{PO}_{4}$, pada rentang orde $10^{-6} \mathrm{~S} / \mathrm{cm}$ dalam bentuk bongkahan (bulk), setara dengan konduktivitas paduan $\mathrm{Li}_{4} \mathrm{P}_{2} \mathrm{O}_{7}$ yang diukur dalam bentuk lapisan tipis pada penelitian terdahulu.

\section{METODE PERCOBAAN}

\section{Bahan dan Alat}

Bahan-bahan yang telah digunakan sebagai prekursor pada pembuatan paduan adalah Lithium carbonate ( $\mathrm{Li}_{2} \mathrm{CO}_{3}$, Alfa Caesar, 99\%), dan Ammonium dihydrogen phosphate $\left(\mathrm{NH}_{4} \mathrm{H}_{2} \mathrm{PO}_{4}\right.$, Merck, 98\%). Digunakan juga aseton $\left(\mathrm{CH}_{3} \mathrm{COCH}_{3}\right.$, Merck, pro analisis) sebagai media untuk mencampur prekursor dan pasta perak (Ag paste, Dotite) sebagai elektroda pengukuran.

Scanning Electron Microscope (SEM) dari JEOL tipe JSM-6510LA yang dilengkapi dengan Energy Dispersive X-Ray Spectrometer (EDS) telah digunakan untuk mengamati morfologi dan analisis elemental dari 
paduan hasil sintesis. Sedangkan untuk karakterisasi elektrokimia dilakukan menggunakan Electrochemical Impedance Spectroscopy (EIS) dari HIOKI LCR tipe HiTESTER 3532-50.

\section{Sintesis Sampel}

$\mathrm{Li}_{2} \mathrm{CO}_{3}$ dan $\mathrm{NH}_{4} \mathrm{H}_{2} \mathrm{PO}_{4}$ dicampurkan dalam media aseton menggunakan pengaduk magnet pada kecepatan $800 \mathrm{rpm}$ dan suhu $50{ }^{\circ} \mathrm{C}$ selama 2 jam. Komposisi pencampuran kedua prekursor tersebut dihitung sehingga didapatkan nilai prosentase berat $\mathrm{Li}_{2} \mathrm{O}$ sebesar $24 \%$ berat dan $28 \%$ berat pada produk hasil.

Setelah dikeringkan pada suhu $80{ }^{\circ} \mathrm{C}$ selama 4 jam, campuran prekursor dipanaskan secara bertahap selama 2,5 jam sampai mencapai suhu $650{ }^{\circ} \mathrm{C}$ dan ditahan pada suhu tersebut selama 2 jam untuk membiarkan prekursornya bereaksi sempurna. Suhu ini jauh berada di bawah titik leleh paduan $\mathrm{Li}_{4} \mathrm{P}_{2} \mathrm{O}_{7}$ stoikiometri sebesar $885{ }^{\circ} \mathrm{C}$. Hasil reaksinya kemudian didinginkan secara cepat dalam media air dan dikeringkan di dalam pemanas pada suhu $120^{\circ} \mathrm{C}$ selama 2 jam.

Morfologi strukturmikro paduan hasil sintesis kemudian diamati menggunakan alat SEM sekaligus melakukan analisa elemental menggunakan EDS. Untuk karakterisasi elektrokimia, paduan dibentuk menjadi pelet berbentuk silinder berdiameter $15 \mathrm{~mm}$, menggunakan tekanan sebesar 15,0 MPa selama 10 menit. Pelet kemudian dipanaskan dalam suhu $100{ }^{\circ} \mathrm{C}$ selama 6 jam untuk menghilangkan tegangan sisa dan kandungan air dalam bahan. Kedua permukaan pellet selanjutnya dilapisi dengan pasta perak yang akan berfungsi sebagai elektroda sekaligus pengumpul arus. Karakterisasi elektrokimia dilakukan menggunakan EIS pada tegangan 1 volt dalam rentang frekuensi $42 \mathrm{~Hz}-1 \mathrm{MHz}$ sebanyak 75 titik. Tata kerja penelitian ini diringkas dalam sebuah diagram alir seperti ditunjukkan oleh Gambar 1.

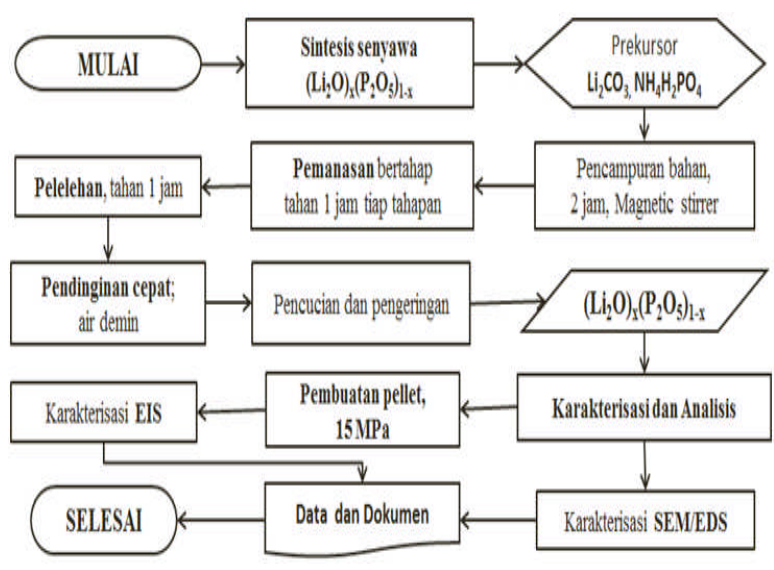

Gambar 1. Diagram alir penelitian

\section{HASIL DAN PEMBAHASAN}

Dari Gambar 2 menunjukkan foto struktur mikro paduan $\left(\mathrm{Li}_{2} \mathrm{O}\right)_{\mathrm{x}}\left(\mathrm{P}_{2} \mathrm{O}_{5}\right)_{\mathrm{y}}$ hasil sintesis menggunakan teknik
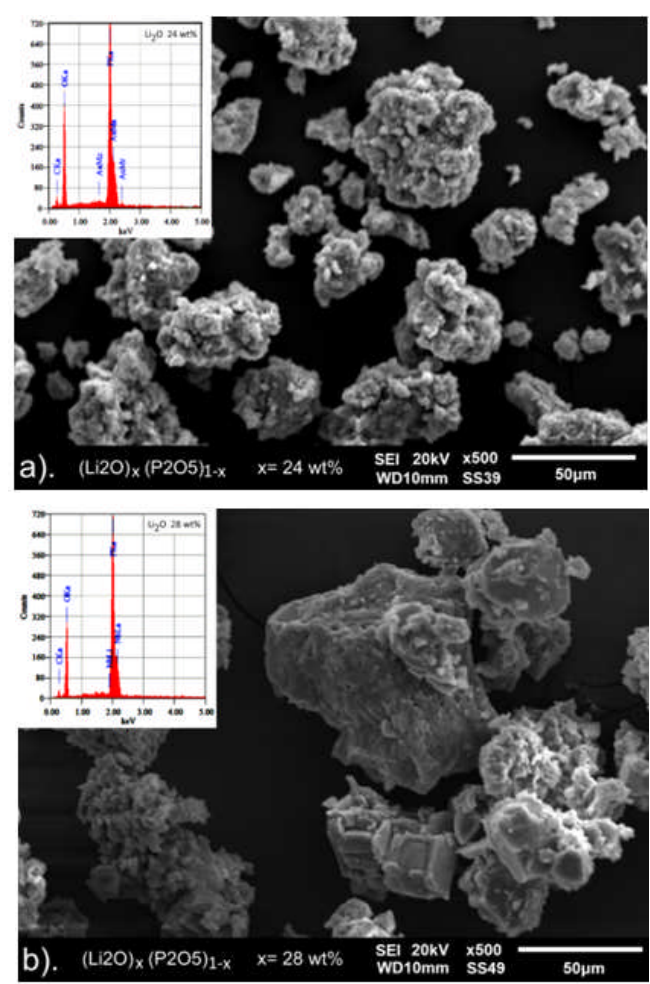

Gambar 2. Foto strukturmikro paduan $\left(\mathrm{Li}_{2} \mathrm{O}_{\mathrm{x}}\left(\mathrm{P}_{2} \mathrm{O}_{5}\right)_{\mathrm{y}}\right.$ Strukturmikro kedua paduan menunjukkan terjadinya aglomerasi. Grafik sisipan pada gambar menunjukkan hasil analisis elemental setiap paduan menggunakan EDS.

"melt-quenching" untuk $\mathrm{x}=24 \%$ berat dan $28 \%$ berat, yang diambil menggunakan SEM. Kedua paduan menunjukkan struktur yang hampir sama, terdiri dari butiran-butiran aglomerat berporos. Pembentukan aglomerat ini menunjukkan bahwa paduan-paduan ini memiliki partikel yang lebih kecil dari ukuran yang terlihat dalam gambar. Aglomerat ini diperkirakan terbentuk pada saat pemanasan bertahap dimana kemungkinan terjadi penggumpalan partikel dalam bahan yang sudah mencair sebagian atau saat proses pendinginan cepat [10].

Ukuran aglomerat pada kedua paduan terlihat berbeda, dimana paduan yang memiliki kandungan $\mathrm{Li}_{2} \mathrm{O}$ lebih banyak, terlihat lebih padat dan lebih besar. Perbedaan ukuran ini diyakini karena senyawa $\mathrm{P}_{2} \mathrm{O}_{5}$ yang terbentuk dari senyawa $\mathrm{NH}_{4} \mathrm{H}_{2} \mathrm{PO}_{4}$ pada proses pemanasan mengalami pelelehan pada suhu yang lebih rendah dibandingkan dengan suhu leleh senyawa $\mathrm{Li}_{2} \mathrm{O}$ dari prekursor $\mathrm{Li}_{2} \mathrm{CO}_{3}$. Penambahan kadar $\mathrm{Li}_{2} \mathrm{O}$ menjadikan lebih banyak partikel serbuk $\mathrm{Li}_{2} \mathrm{O}$ yang menggumpal dalam lelehan $\mathrm{P}_{2} \mathrm{O}_{5}$ yang berakibat pada pembesaran ukuran aglomerat.

Analisis elemental menggunakan EDS menunjukkan bahwa kedua paduan didominasi oleh unsur Fosfor (P) dan Oksigen (O). Energi emisi sinar-X karakteristik dari unsur Lithium (Li) dalam paduan, tidak terdeteksi oleh detektor EDS yang digunakan, karena energinya akan terserap oleh logam Berilium yang digunakan sebagai lapisan pengaman permukaan detektor. Unsur karbon (C) yang terdeteksi dalam jumlah 


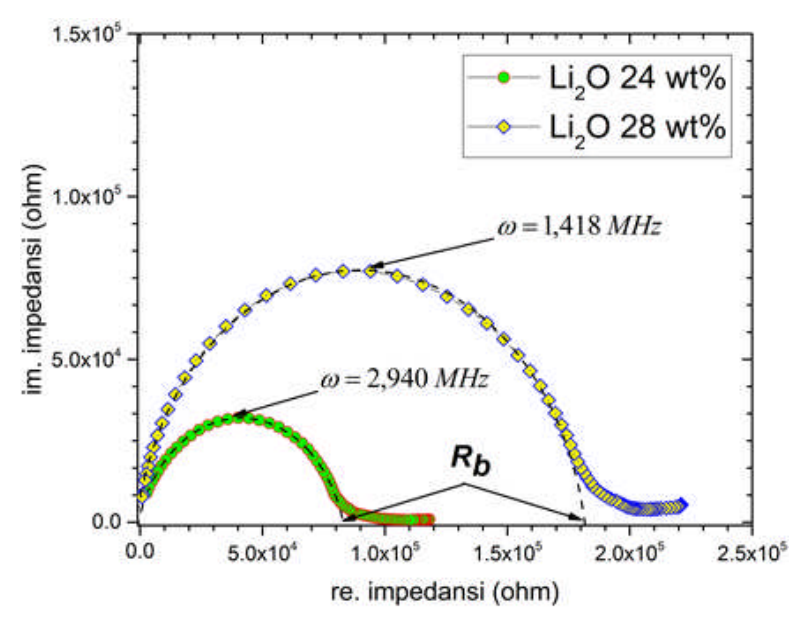

Gambar 3. Kurva impedansi paduan $\left(\mathrm{Li}_{2} \mathrm{O}\right)_{\mathrm{x}}\left(\mathrm{P}_{2} \mathrm{O}_{5}\right)_{\mathrm{y}}$ untuk $\mathrm{x}=24$ dan $28 \%$ berat dimana $\mathrm{y}=(100-\mathrm{x}) \%$ berat.

kecil kemungkinan berasal dari polimer pada selotip untuk merekatkan sampel.

Kurva hubungan Impedansi resistif dengan impedansi kapasitif dari paduan $\left(\mathrm{Li}_{2} \mathrm{O}\right)_{\mathrm{x}}\left(\mathrm{P}_{2} \mathrm{O}_{5}\right)_{\mathrm{y}}$ ditunjukkan oleh Gambar 3. Kedua paduan memiliki kurva impedansi yang cenderung sama, terbentuk dari sebuah busur setengah lingkaran pada frekuensi tinggi dengan ekor pada frekuensi rendah. Ekor pada frekuensi rendah merupakan efek dari kapasitansi lapis ganda (dual layer capacitance) pada daerah antar muka elektrolit dan elektroda, sedangkan busur setengan lingkaran merupakan respon impedansi dari bulk elektrolit [22].

Nilai resistansi dan kapasitansi bulk kedua sampel bisa dihitung dengan cara menganalogikan kurva busur setengah lingkaran pada kurva sebagai sebuah sirkuit yang terdiri dari resistor dan kapasitor yang terhubung secara parallel. Nilai resistansi bulk ditentukan dari perpotongan busur dengan sumbu axis, sedangkan nilai kapasitansi dihitung menggunakan nilai resistansi dan nilai frekuensi relaksasi, yaitu frekuensi pada puncak busur setengah lingkaran [23]. Sedangkan waktu relaksasi atau waktu yang digunakan partikel untuk mencapai posisi stabil pada sebuah respon dari luar, dihitung dari nilai frequensi relaksasi.

Tabel 1 menunjukkan nilai-nilai parameter impedansi untuk paduan $\left(\mathrm{Li}_{2} \mathrm{O}\right)_{\mathrm{x}}\left(\mathrm{P}_{2} \mathrm{O}_{5}\right)_{\text {y }}$ dengan $\mathrm{x}=24$ \%berat dan $28 \%$ berat yang didapatkan dari Gambar 3. Paduan $\left(\mathrm{Li}_{2} \mathrm{O}\right)_{\mathrm{x}}\left(\mathrm{P}_{2} \mathrm{O}_{5}\right)_{\mathrm{y}}$ dengan kandungan $\mathrm{Li}_{2} \mathrm{O}$ sebesar $\mathrm{x}=28 \%$ berat mempunyai resistansi bulk yang lebih besar dibandingkan dengan paduan $\mathrm{x}=24 \%$ berat

Tabel 1. Parameter impedansi paduan $\left(\mathrm{Li}_{2} \mathrm{O}\right)_{\mathrm{x}}\left(\mathrm{P}_{2} \mathrm{O}_{5}\right)_{\mathrm{y}}$ untuk $\mathrm{x}=24 \%$ berat dan $28 \%$ berat yang didapatkan dari kurva impedansi pada Gambar 3.

\begin{tabular}{lccc}
\hline \multicolumn{2}{c}{$\left(\mathrm{Li}_{2} \mathrm{O}\right)_{\mathrm{x}}\left(\mathrm{P}_{2} \mathrm{O}_{5}\right)_{\mathrm{y}}$} & $\mathrm{x}=24 \%$ berat & $\mathrm{x}=28 \%$ berat \\
\hline Resistansi bulk & $R_{b}(\Omega)$ & $8,296 \times 10^{4}$ & $1,816 \times 10^{5}$ \\
Frekuensi Relaksasi & $\omega(\mathrm{Hz})$ & $2,940 \times 10^{6}$ & $1,418 \times 10^{6}$ \\
Waktu Relaksasi & $\tau(\mathrm{s})$ & $3,401 \times 10^{-7}$ & $7,050 \times 10^{-7}$ \\
Kapasitansi bulk & $C_{b}(\mathrm{~F})$ & $4,134 \times 10^{-12}$ & $3,849 \times 10^{-12}$ \\
\hline
\end{tabular}

Paduan ini juga memiliki frekuensi relaksasi yang lebih kecil, sehingga memiliki waktu relaksasi yang lebih besar dibandingkan dengan paduan $\mathrm{x}=24 \%$ berat. Ini berarti bahwa paduan $\mathrm{x}=28 \%$ berat memiliki waktu lebih panjang untuk mencapai kestabilan akibat respon terhadap medan listrik yang diberikan. Hal ini berkaitan dengan struktur mikro bahan dimana paduan yang memiliki kandungan $\mathrm{Li}_{2} \mathrm{O}$ lebih banyak, memiliki ukuran aglomerat lebih besar dibandingkan paduan $\mathrm{x}=24 \%$ berat (Gambar 2), yang memberikan resistansi lebih besar terhadap medan listrik, sehingga memberikan respon relaksasi yang lebih lamban terhadap medan listrik yang diberikan.

Gambar 4 menunjukkan kurva nilai impedansi dalam fungsi frekuensi pengukuran untuk paduan $\left(\mathrm{Li}_{2} \mathrm{O}\right)_{\mathrm{x}}\left(\mathrm{P}_{2} \mathrm{O}_{5}\right)_{\mathrm{y}}$ dengan $\mathrm{x}=24 \%$ berat dan $28 \%$ berat, untuk impedansi resistif (bagian riil impedansi) dan impedansi kapasitif (bagian imajiner impedansi). Seperti halnya kurva impedansi pada Gambar 3, bagian riil dan imajiner impedansi kedua paduan memiliki kecenderungan ketergantungan yang sama terhadap frekuensi pengukuran.
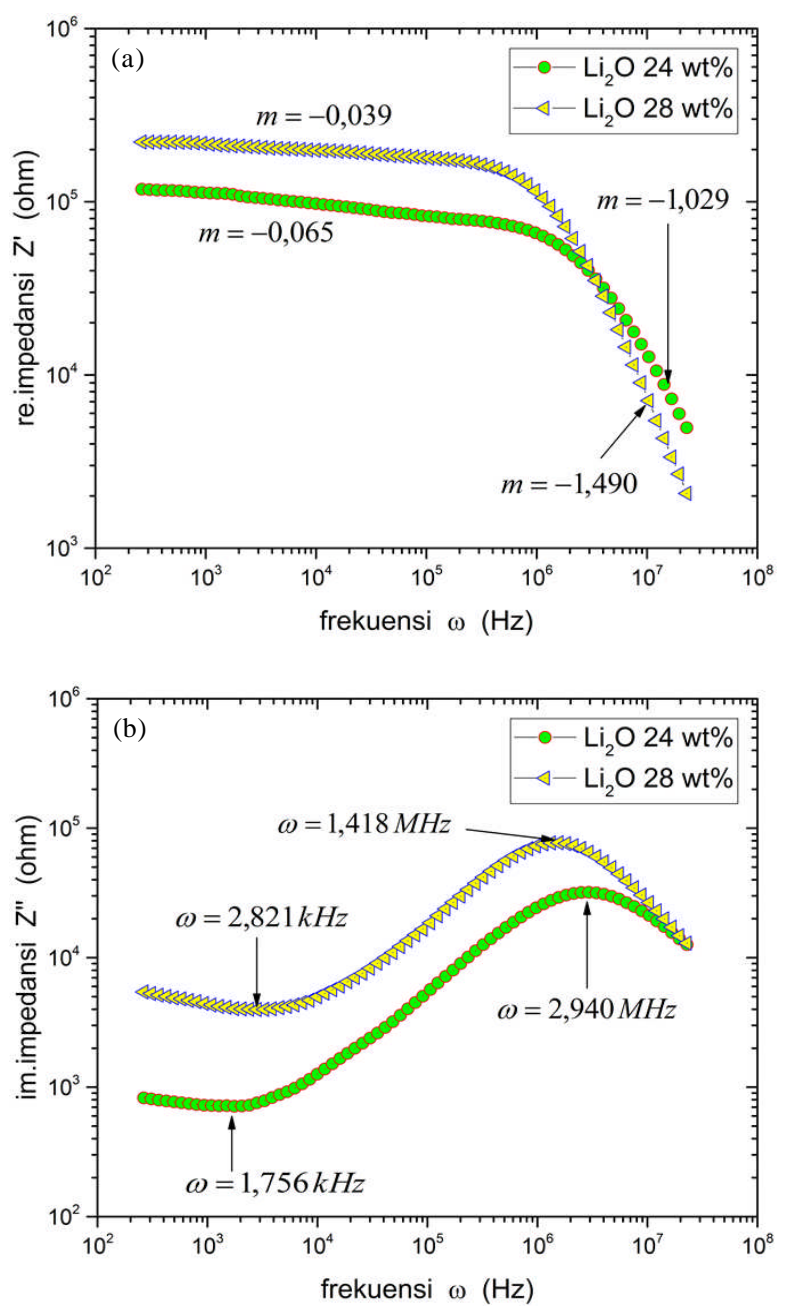

Gambar 4. Kurva impedansi paduan $\left(\mathrm{Li}_{2} \mathrm{O}\right)_{x}\left(\mathrm{P}_{2} \mathrm{O}_{5}\right)_{y}$ dengan nilai $\mathrm{x}=24 \%$ berat dan $28 \%$ berat sebagai fungsi frekuensi (a). impedansi resistif dan (b). impedansi kapasitif. 
Pada frekuensi rendah impedansi resistif kedua paduan cenderung menurun dengan ratio penurunan $(\mathrm{m})$ yang hampir sama seiring dengan kenaikan frekuensi, dimana paduan $\left(\mathrm{Li}_{2} \mathrm{O}\right)_{\mathrm{x}}\left(\mathrm{P}_{2} \mathrm{O}_{5}\right)_{\mathrm{y}}$ yang memiliki kandungan $\mathrm{Li}_{2} \mathrm{O}$ lebih banyak memiliki nilai impedansi resistif yang lebih besar. Namun pada frekuensi lebih besar dari $\omega=1$ $\mathrm{MHz}$, nilai keduanya menurun dengan cepat dimana paduan yang memiliki kandungan $\mathrm{Li}_{2} \mathrm{O}$ lebih banyak menunjukkan penurunan yang lebih besar, sehingga berakibat pada nilai resistansinya menjadi lebih kecil dibandingkan sebaliknya.

Impedansi kapasitif kedua paduan juga memiliki kecenderungan yang sama, dimana paduan yang memiliki kandungan $\mathrm{Li}_{2} \mathrm{O}$ lebih banyak memiliki nilai impedansi kapasitif lebih rendah pada semua nilai frekuensi pengukuran, yang berakibat pada nilai kapasitansi yang lebih rendah pula. Kurva impedansi kapasitif ini memiliki lembah dan puncak pada frekuensi-frekuensi yang sama seperti yang telah ditunjukkan pada Gambar 3 .

Konduktivitas paduan $\left(\mathrm{Li}_{2} \mathrm{O}\right)_{\mathrm{x}}\left(\mathrm{P}_{2} \mathrm{O}_{5}\right)_{\mathrm{y}}$ sebagai fungsi frekuensi pengukuran ditunjukkan pada Gambar 5. Nilai konduktivitas dihitung dari nilai impedansi kompleks hasil pengukuran, dengan mempertimbangkan parameter ketebalan sampel dan luas permukaan kontak antara sampel dengan elektroda. Nilai konduktivitas kompleks suatu material bervariasi terhadap frekuensi angular $\omega$ dengan mengikuti persamaan Jonscher seperti pada Persamaan (1) [24],

$$
\sigma(\omega)=\sigma_{d c}+A \omega^{n}
$$

Dimana:

$$
\begin{aligned}
\sigma_{d c} & =\text { Konduktivitas DC } \\
A^{A} & =\text { Konstanta } \\
n & =\text { Konstanta }
\end{aligned}
$$

Untuk mendapatkan nilai parameter-parameter tersebut, kurva konduktivitas hasil pengukuran impedansi

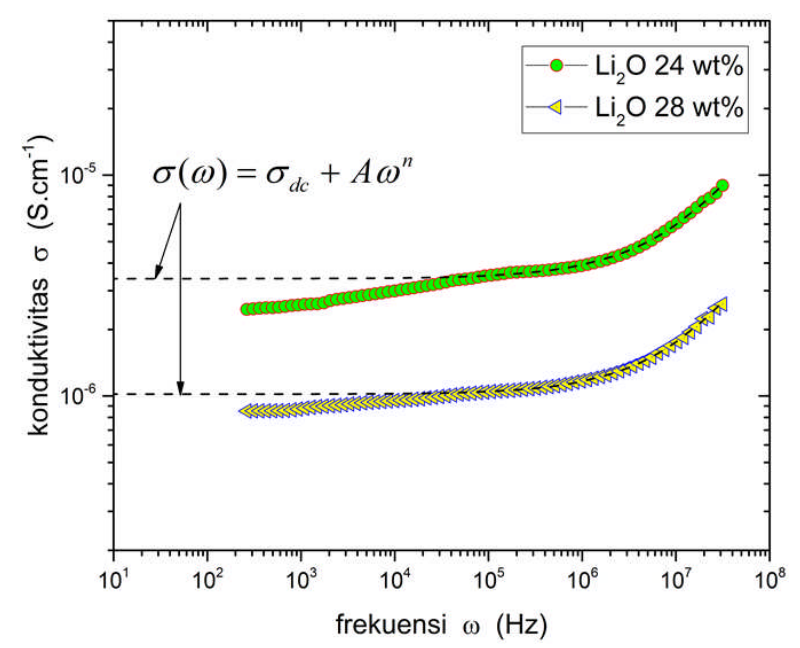

Gambar 5. Kurva konduktivitas kompleks paduan $\left(\mathrm{Li}_{2} \mathrm{O}\right)_{\mathrm{x}}\left(\mathrm{P}_{2} \mathrm{O}_{5}\right)_{\mathrm{y}}$ dengan nilai $\mathrm{x}=24 \%$ berat dan $28 \%$ berat sebagai fungsi frekuensi pengukuran. dicocokkan terhadap Persamaan (1) menggunakan prosedur non-linear least square fitting. Nilai parameter hasil pencocokkan tersebut disajikan pada Tabel 2.

Tabel 2. Nilai-nilai parameter konduktivitas paduan $\left(\mathrm{Li}_{2} \mathrm{O}\right)_{\mathrm{x}}\left(\mathrm{P}_{2} \mathrm{O}_{5}\right)_{\mathrm{y}}$ untuk $\mathrm{x}=24 \%$ berat dan $28 \%$ berat, hasil pencocokkan kurva konduktivitas Gambar 5 terhadap Persamaan Jonscher. Konduktivitas paduan dengan nilai $x=29,6 \%$ berat $\left(\mathrm{Li}_{4} \mathrm{P}_{2} \mathrm{O}_{7}\right)$ dan $\mathrm{x}=38,7 \%$ berat $\left(\mathrm{Li}_{3} \mathrm{PO}_{4}\right)$ masing-masing didapatkan dari referensi [20] dan [5].

\begin{tabular}{ccccc}
\hline x \%berat & 24 & 28 & 29,6 & 38,7 \\
\hline$\sigma_{d c}(\mathrm{~S} / \mathrm{cm})$ & $3,40 \times 10^{-6}$ & $1,02 \times 10^{-6}$ & $6,78 \times 10^{-6}$ & $7,70 \times 10^{-9}$ \\
$A$ & $4,11 \times 10^{-11}$ & $8,44 \times 10^{-12}$ & n.a. & $4,06 \times 10^{-11}$ \\
$n$ & 0,685 & 0,706 & n.a. & 0,528 \\
\hline
\end{tabular}

Nilai konduktivitas dc kedua paduan berada pada orde yang sama yaitu pada orde $10^{-6} \mathrm{~S} / \mathrm{cm}$, tiga orde lebih besar bila dibandingkan dengan nilai konduktivitas senyawa $\mathrm{Li}_{3} \mathrm{PO}_{4}[5]$. Nilai konduktivitas ini setara dengan nilai konduktivitas senyawa $\mathrm{Li}_{4} \mathrm{P}_{2} \mathrm{O}_{7}[20]$. Nilai eksponen frekuensi kedua paduan berada pada rentang nilai $n=0,69 \sim 0,71$, menunjukkan bahwa kemungkinan sumber konduksi didalam kedua paduan ini salah satunya adalah konduksi dari aliran ion jarak jauh [25]. Konduktivitas tinggi, suhu reaksi rendah, kandungan $\mathrm{Li}_{2} \mathrm{O}$ rendah menjadi nilai penting bagi kedua paduan pada studi ini, karena $\mathrm{Li}_{3} \mathrm{PO}_{4}$ dan $\mathrm{Li}_{4} \mathrm{P}_{2} \mathrm{O}_{7}$ yang didapatkan pada referensi terdahulu disintesis dengan reaksi padatan pada suhu yang jauh lebih tinggi dan dengan komposisi kandungan $\mathrm{Li}_{2} \mathrm{O}$ yang lebih banyak. Selain itu, nilai konduktivitas paduan pada studi ini diukur pada kondisi bulk dengan ketebalan 2-3 mm, berbeda dengan pengukuran konduktivitas senyawa $\mathrm{Li}_{4} \mathrm{P}_{2} \mathrm{O}_{7}$ di referensi [20] yang diukur dalam bentuk lapisan tipis dengan ketebalan kurang dari $0,5 \mathrm{~mm}$. Pembentukan paduan menjadi lapisan tipis diyakini mampu menurunkan resistansi bulk paduan, sehingga akan meningkatkan nilai konduktivitasnya.

Peningkatan nilai konten $\mathrm{Li}_{2} \mathrm{O}$ dalam paduan diharapkan mampu meningkatkan jumlah ion yang bergerak di dalam paduan sehingga akan menaikkan konduktivitasnya. Akan tetapi dalam penelitian ini penambahan konten $\mathrm{Li}_{2} \mathrm{O}$ menjadi $28 \%$ berat tidak meningkatkan konduktivitas paduan.

Hal ini kemungkinan terjadi karena kedua paduan yang disintesis dalam studi ini memiliki struktur yang sama seperti yang diusulkan oleh Nakano, dkk melalui diagram fasanya [26]. Karakterisasi lebih lanjut seperti menggunakan Difraksi Sinar-X dibutuhkan untuk mengetahui struktur kristal dari paduan yang terbentuk.

Perbedaan kecil nilai konduktivitas kedua paduan diyakini diakibatkan oleh meningkatnya nilai resistansi bulk paduan seperti yang terlihat dari kurva impedansi (Gambar 3) akibat meningkatnya ukuran aglomerat pada struktur mikro paduan (Gambar 2). Perlakuan lanjutan seperti perlakuan untuk menurunkan ukuran butir dan resistansi bulk, dan penambahan sumber ion Lithium 
yang lain, diharapkan mampu menaikkan konduktivitas paduan ini.

Pada saat medan listrik diaplikasikan melewati sebuah media dielektrik, kekuatan medan untuk melewati media tersebut dipengaruhi oleh kemampuan media untuk terpolarisasi sebagai respon terhadap medan tersebut. Parameter kekuatan media untuk melewatkan medan listrik disebut permittivitas. Bagian riil dari permittivitas kompleks sering disebut konstanta dielektrik atau konstanta dielektrik relatif (dielectric gain) menunjukkan berapa banyak energi dari luar bisa disimpan di dalam media, sedangkan bagian imajiner disebut rugi dielektrik (dielectric loss) yang menunjukkan seberapa disipatif sebuah media terhadap sebuah medan listrik luar. Kurva permittivitas kompleks paduan $\left(\mathrm{Li}_{2} \mathrm{O}\right)_{\mathrm{x}}\left(\mathrm{P}_{2} \mathrm{O}_{5}\right)_{\mathrm{y}}$ sebagai fungsi frekuensi $\omega$, ditunjukkan pada Gambar 6 yang dihitung dari nilai impedansi hasil pengukuran.
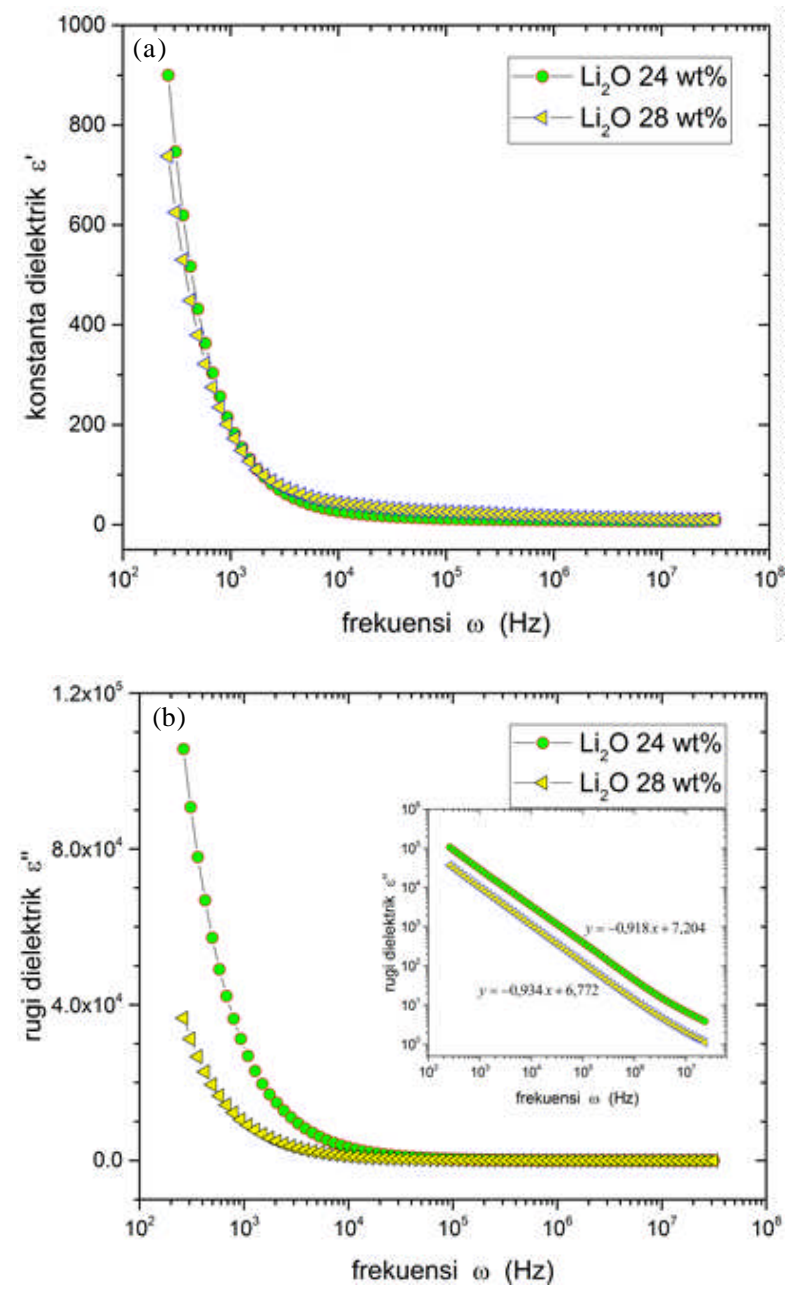

Gambar 6. Kurva permittivitas paduan $\left(\mathrm{Li}_{2} \mathrm{O}\right)_{x}\left(\mathrm{P}_{2} \mathrm{O}_{5}\right)_{y}$ sebagai fungsi frekuensi pengukuran, untuk $\mathrm{x}=24 \%$ berat dan $28 \%$ berat. (a). konstanta dielektrik dan (b). rugi dielektrik. Gambar sisipan adalah grafik yang sama dalam format $\log -\log$.

Pada frekuensi rendah terjadi dispersi yang cukup kuat pada grafik kedua permittivitas (riil dan imajiner) dimana terjadi kenaikan nilai permittivitas yang drastis seiring dengan penurunan frekuensi. Untuk bagian riil kurva permittivitas, fenomena pada frekuensi rendah ini merupakan hasil kontribusi kuat dari akumulasi muatan pada daerah antar muka elektrolit dan elektroda [27], sedangkan untuk kurva rugi dielektrik merupakan akibat dari perpindahan ion di dalam material [28], seperti yang digambarkan sebagai ekor pada ujung kurva impedansi pada Gambar 3. Nilai permittivitas tersebut kemudian diikuti oleh daerah yang hampir tidak bergantung frekuensi pada daerah frekuensi lebih tinggi, yang diakibatkan oleh pembalikan medan listrik secara periodik dan cepat, yang mengakibatkan tidak ada lagi difusi dan vibrasi ion yang tersisa pada daerah frekuensi tersebut [29].

Nilai konstanta dielektrik untuk kedua paduan $\left(\mathrm{Li}_{2} \mathrm{O}\right)_{\mathrm{x}}\left(\mathrm{P}_{2} \mathrm{O}_{5}\right)_{\mathrm{y}}$ menunjukkan nilai yang tidak jauh berbeda pada semua rentang frekuensi pengukuran. Sedangkan untuk nilai rugi dielektrik, perbedaan terjadi pada daerah frekuensi rendah dimana paduan $\left(\mathrm{Li}_{2} \mathrm{O}\right)_{\mathrm{x}}\left(\mathrm{P}_{2} \mathrm{O}_{5}\right)_{\mathrm{y}}$ dengan nilai $\mathrm{x}=28 \%$ berat memiliki nilai yang lebih rendah dibandingkan dengan paduan $\mathrm{x}=24 \%$ berat. Akan tetapi pada daerah frekuensi lebih tinggi, kedua paduan menunjukkan nilai rugi dielektrik yang tidak jauh berbeda. Dari grafik log rugi dielektrik terhadap log frekuensi diketahui bahwa kedua paduan memiliki kurva garis lurus yang hampir sejajar, dengan nilai kemiringan $m=-0,918 \sim-0,934$ yang mendekati nilai -1. Nilai tersebut menunjukkan bahwa konduksi pada kedua paduan $\left(\mathrm{Li}_{2} \mathrm{O}\right)_{\mathrm{x}}\left(\mathrm{P}_{2} \mathrm{O}_{5}\right)_{\mathrm{y}}$ didominasi oleh konduksi DC.

Perbandingan nilai rugi dielektrik terhadap konstanta dielektrik untuk semua frekuensi pengukuran ditunjukkan oleh kurva tandelta pada Gambar 7. Tandelta adalah parameter yang menunjukkan faktor dissipasi atau rasio kehilangan energi medan listrik yang diakibatkan oleh pengaruh media dielektrik yang dilewatinya. Kurva tandelta untuk kedua paduan $\left(\mathrm{Li}_{2} \mathrm{O}\right)_{\mathrm{x}}\left(\mathrm{P}_{2} \mathrm{O}_{5}\right)_{\mathrm{y}}$ memiliki kecenderungan yang sama yaitu memiliki puncak pada

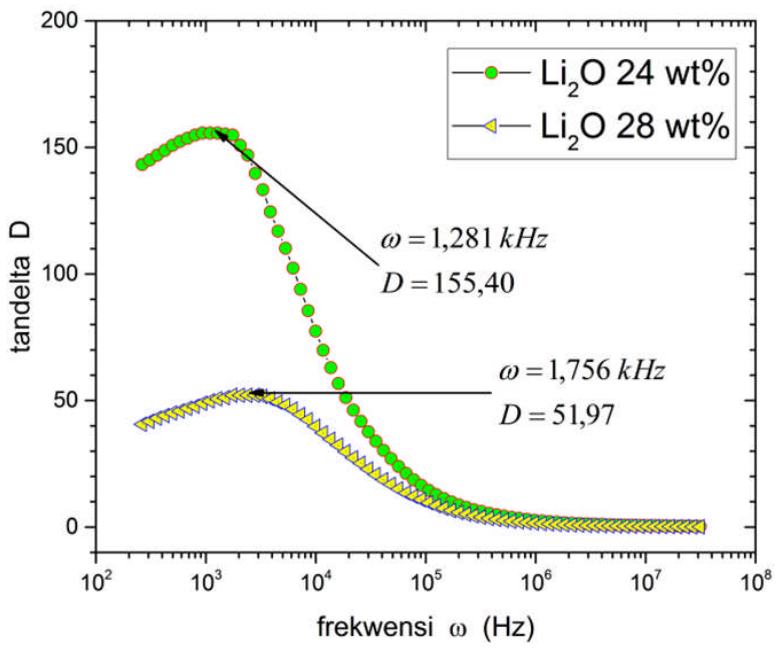

Gambar 7. Kurva faktor dissipasi (tandelta) paduan $\mathrm{x}\left(\mathrm{Li}_{2} \mathrm{O}\right) \cdot \mathrm{y}\left(\mathrm{P}_{2} \mathrm{O}_{5}\right)$ sebagai fungsi pengukuran untuk $\mathrm{x}=24 \%$ berat dan $28 \%$ berat. 
frekuensi rendah dan cenderung konstan pada frekuensi tinggi. Puncak tandelta untuk kedua paduan terjadi pada frekuensi $\omega=1,281 \mathrm{kHz}$ dan $\omega=1,756 \mathrm{kHz}$ untuk $\mathrm{x}=24 \%$ berat dan $28 \%$ berat, dengan nilai tandelta masing-masing $\mathrm{D}=155,40$ dan $\mathrm{D}=51,97$. Pergeseran puncak tandelta ini menunjukkan adanya penambahan fenomena relaksasi dielektrik pada media paduan yang menyebabkan peningkatan probabilitas loncatan ion dalam paduan [30].

\section{KESIMPULAN}

Telah berhasil dilakukan sistesis elektrolit padat sistem baru paduan $\left(\mathrm{Li}_{2} \mathrm{O}\right)_{\mathrm{x}}\left(\mathrm{P}_{2} \mathrm{O}_{5}\right)_{\mathrm{y}}$ pada komposisi kandungan $\mathrm{Li}_{2} \mathrm{O}$ sebesar $\mathrm{x}=24 \%$ berat dan $28 \%$ berat melalu metode reaksi padat pada suhu di bawah suhu leleh paduan $\mathrm{Li}_{4} \mathrm{P}_{2} \mathrm{O}_{7}$. Morfologi kedua paduan memiliki sifat yang hampir sama yaitu cenderung membentuk butir-butir aglomerat. Perbedaan nilai resistansi bulk kedua paduan kemungkinan diakibatkan oleh perbedaan ukuran aglomerat. Nilai konduktivitas kedua paduan berada pada orde $10^{-6} \mathrm{~S} / \mathrm{cm}$ yang berarti lebih besar tiga orde dibandingkan dengan nilai konduktivitas paduan $\mathrm{Li}_{3} \mathrm{PO}_{4}$ dan setara dengan konduktivitas paduan $\mathrm{Li}_{4} \mathrm{P}_{2} \mathrm{O}_{7}$ yang memiliki kandungan $\mathrm{Li}_{2} \mathrm{O}$ lebih banyak dan suhu sintesis lebih tinggi.Sumber konduksi dalam kedua paduan ini salah satunya diperkirakan berasal dari aliran ion jarak jauh dan didominasi oleh konduksi DC. Penelitian dan analisis lebih lanjut diperlukan untuk mengetahui struktur paduan yang telah disintesis dalam studi ini, untuk pengembangan dan peningkatan performanya.

\section{UCAPAN TERIMAKASIH}

Tim penulis mengucapkan terimakasih yang sebesar-besarnya kepada para kolega, peneliti dan pembimbing di PSTBM BATAN dan DTMM-UI atas segala bantuan, ide dan kontribusinya untuk kelancaran penelitian dan terlaksananya penulisan makalah ini.

\section{DAFTAR ACUAN}

[1]. V. A. Agubra and J. W. Fergus. "The Formation and Stability of the Solid Electrolyte Interface on the Graphite Anode." J. Power Sources, vol. 268, pp. 153-162, Dec. 2014.

[2]. M. Kotobuki. "The Current Situation and Problems of Rechargeable Lithium Ion Batteries." Open Electrochem. J., vol. 4, pp. 28-35, 2012.

[3]. G. Sahu, Z. Lin, J. Li, Z. Liu, N. Dudney, and C. Liang. "Air-stable, High-Conduction Solid Electrolytes of Arsenic-Substituted $\mathrm{Li}_{4} \mathrm{SnS}_{4}$." Energy Environ. Sci., vol. 7, no. 3, pp. 1053-1058, 2014.

[4]. E. Quartarone and P. Mustarelli. "Electrolytes for Solid-State Lithium Rechargeable Batteries: Recent
Advances and Perspectives." Chem. Soc. Rev., vol. 40, no. 5, pp. 2525-2540, 2011.

[5]. H. Jodi, Supardi, E. Kartini, and A. Zulfi. "Synthesis And Electrochemical Characterization of $\mathrm{Li}_{3} \mathrm{PO}_{4}$ for Solid State Electrolytes.” J. Sains Mater. Indones., vol. 18, no. 1, pp. 1-8, 2016.

[6]. A. Nur I. P., E. Kartini, L. Dwi Prayogi, M. Faisal, and Supardi. "Crystal Structure Analysis of $\mathrm{Li}_{3} \mathrm{PO}_{4}$ Powder Prepared by Wet Chemical Reaction and Solid State Reaction by Using X-Ray Diffraction (XRD)." Ionics, Int. J. Ionics Sci. Technol. Ion. Motion, vol. 22, no. 7, pp. 1051-1057, 2016.

[7]. A. K. Jahja, T. Y. S. P. Putra, H. Mugirahardjo, Supardi, A. Insani, and E. Kartini. "Analisis Struktural Bahan Elektrolit $\left(\mathrm{Li}_{2} \mathrm{O}\right)_{\mathrm{x}}\left(\mathrm{P}_{2} \mathrm{O}_{5}\right)_{\mathrm{y}}(\mathrm{x}=5, \mathrm{y}=1)$ dengan Metoda Difraksi Neutron Resolusi Tinggi." in Prosiding Seminar Nasional Hamburan Neutron dan Sinar-X, pp. 23-31.

[8]. N. D. Lepley and N. A. W. Holzwarth. "Computer Modeling of Crystalline Electrolytes: Lithium Thiophosphates and Phosphates." J. Electrochem. Soc. , vol. 159, no. 5, pp. A538-A547, Jan. 2012.

[9]. N. D. Lepley, N. A. W. Holzwarth, and Y. A. Du. "Structures, $\mathrm{Li}^{+}$Mobilities, and Interfacial Properties of Solid Electrolytes $\mathrm{Li}_{3} \mathrm{PS}_{4}$ and $\mathrm{Li}_{3} \mathrm{PO}_{4}$ from First Principles.” Phys. Rev. B, vol. 88, no. 10, p. 104103, Sep. 2013.

[10]. L. D. Prayogi, M. Faisal, E. Kartini, W. Honggowiranto, and Supardi. "Morphology and Conductivity Study of Solid Electrolyte $\mathrm{Li}_{3} \mathrm{PO}_{4}$." in AIP Conference Proceedings 1710, 030047, 2016.

[11]. B. Raguenet, G. Tricot, G. Silly, M. Ribes, and A. Pradel. "The Mixed Glass Former Effect in TwinRoller Quenched Lithium Borophosphate Glasses." Solid State Ionics, vol. 208, pp. 25-30, Feb. 2012.

[12]. M. Kotobuki and M. Koishi. "Preparation of $\mathrm{Li}_{1.5} \mathrm{Al}_{0.5} \mathrm{Ti}_{1.5}\left(\mathrm{PO}_{4}\right)_{3}$ Solid Electrolyte Via a Sol-Gel Route Using Various Al Sources." Ceram. Int., vol. 39, no. 4, pp. 4645-4649, May 2013.

[13]. H. Chung and B. Kang. "Increase in Grain Boundary Ionic Conductivity of $\mathrm{Li}_{1.5} \mathrm{Al}_{0.5} \mathrm{Ge}_{1.5}\left(\mathrm{PO}_{4}\right)_{3}$ by Adding Excess Lithium." Solid State Ionics, vol. 263, pp. 125-130, Oct. 2014.

[14]. P. Goharian, A. R. Aghaei, B. E. Yekta, and S. Banijamali. "Ionic Conductivity and Microstructural Evaluation of $\mathrm{Li}_{2} \mathrm{O}-\mathrm{TiO}_{2}-\mathrm{P}_{2} \mathrm{O}_{5}-\mathrm{SiO}_{2}$ Glass-Ceramics.” Ceram. Int., vol. 41, no. 1, Part B, pp. 1757-1763, Jan. 2015.

[15]. A. Zaafouri, M. Megdiche and M. Gargouri. "AC Conductivity and Dielectric Behavior in Lithium and Sodium Diphosphate $\mathrm{LiNa}_{3} \mathrm{P}_{2} \mathrm{O}_{7}$." J. Alloys Compd., vol. 584, pp. 152-158, Jan. 2014.

[16]. E. Kartini, M. Nakamura, M. Arai, Y. Inamura, K. Nakajima, T. Maksum, W. Honggowiranto and T.Y.S.P. Putra. "Structure and Dynamics of Solid Electrolyte $(\mathrm{LiI})_{0.3}\left(\mathrm{LiPO}_{3}\right)_{0.7}$." Solid State Ionics, vol. 262, pp. 833-836, Sep. 2014. 
[17] D. P. Singh, K. Shahi, and K. K. Kar. "Scaling Behavior and Nearly Constant Loss Effect in AgI$\mathrm{LiPO}_{3}$ Composite Glasses." Solid State Ionics, vol. 231, pp. 102-108, Feb. 2013.

[18] H. Jodi, A. Zulfia, Deswita, and E. Kartini. "A Study of the Structural and Electrochemical Properties of $\mathrm{Li}_{3} \mathrm{PO}_{4}$-MMT-PVDF Composites for Solid Electrolytes." Int. J. Technol., vol. 7, no. 8, pp. 1291-1300, 2016.

[19] K. Senevirathne, C. S. Day, M. D. Gross, A. Lachgar, and N.A. W. Holzwarth. "ANew Crystalline LiPON Electrolyte: Synthesis, Properties and Electronic Structure," Solid State Ionics, vol. 233, pp. 95-101, Feb. 2013

[20] E. Kartini, W. Honggowiranto, H. Jodi, and A. K. Jahya. "Synthesis and Characterization of New Solid Electrolyte Layer $\left(\mathrm{Li}_{2} \mathrm{O}\right)_{\mathrm{x}}\left(\mathrm{P}_{2} \mathrm{O}_{5}\right)_{\mathrm{y}}$ " " in $14^{\text {th }}$ Asian Conference on Solid State Ionics, vol. 2, pp. 163-173, 2014

[21] J. Nakano, T. Yamada, and S. Miyazawa, "Phase Diagram for a Portion of the System $\mathrm{Li}_{2} \mathrm{O}-\mathrm{Nd}_{2} \mathrm{O}_{3}$ $\mathrm{P}_{2} \mathrm{O}_{5}$." J. Am. Ceram. Soc., vol. 62, no. 9-10, pp. 465-467, Sep. 1979.

[22] N. Chilaka and S. Ghosh, "Dielectric Studies of Poly (Ethylene glycol)-Polyurethane/Poly (Methylmethacrylate)/Montmorillonite Composite." Electrochim. Acta, vol. 134, pp. 232-241, Jul. 2014.

[23] S. Rudhziah, N. S. Mohamed, and A. Ahmad. "Conductivity and Structural Studies of Poly(Vinylidene Fluoride co-Hexafluoropropylene)/ Polyethyl Methacrylate Blend Doped with Ammonium Triflate." International Journal of Electrochemical Science, vol. 8, no. 1.pp. 421-434, Jan 2013.
[24] A. K. Jonscher. "The / universal/' dielectric response." Nature, vol. 267, no. 5613, pp. 673-679, Jun. 1977.

[25] H.-W. Chen, C.-Y. Chiu, H.-D. Wu, I.-W. Shen, and F.-C. Chang. "Solid-State Electrolyte Nanocomposites Based on Poly(Ethylene Oxide), Poly(Oxypropylene) Diamine, Mineral Clay and Lithium Perchlorate." Polymer (Guildf)., vol. 43, no. 18, pp. 5011-5016, Aug. 2002.

[26] J. Nakano, T. Yamada, and S. Miyazawa, "Phase Diagram for a Portion of the System $\mathrm{Li}_{2} \mathrm{O}-\mathrm{Nd}_{2} \mathrm{O}_{3}$ $\mathrm{P}_{2} \mathrm{O}_{5}$." J. Am. Ceram. Soc., vol. 62, no. 9-10, pp. 465-467, Sep. 1979.

[27] H. Nithya, S. Selvasekarapandian, P. Christopher Selvin, D. Arun Kumar, and J. Kawamura. "Effect of Propylene Carbonate and Dimethylformamide on Ionic Conductivity of $\mathrm{P}(\mathrm{ECH}-\mathrm{EO})$ Based Polymer Electrolyte." Electrochim. Acta, vol. 66, pp. 110-120, Apr. 2012.

[28] N. S. Adnan, S. B. R. S; Mohamed. "Conductivity and Dielectric Studies of $\mathrm{Li}_{2} \mathrm{ZnSiO}_{4}$ Ceramic Electrolyte Synthesized via Citrate Sol Gel Method.” Int. J. Electrochem. Sci., vol. 7, no. 10, p. 9844, 2012.

[29] V. Kumar, T, A. S. Chary, S. Bhardwaj, A. M. Awasthi, and S. N. Reddy, "Dielectric Relaxation, Ionic Conduction and Complex Impedance Studies on $\mathrm{NaNo}_{3}$ Fast Ion Conductor.” Int. J. Mater. Sci. Appl., vol. 2, no. 6, pp. 173-178, 2013.

[30] Sudaryanto, E. Yulianti, and H. Jodi. "Studies of Dielectric Properties and Conductivity of ChitosanLithium Triflate Electrolyte." Polym. Plast. Technol. Eng., vol. 54, no. 3, pp. 290-295, Feb. 2015. 